УДК 94 : [332.2.01 : 338.43.02] (477) (045)

DOI: https://doi.org/10.33782/eminak2020.4(32).467

\title{
AGRARIAN POLICY IN UKRAINE DURING THE NATIONAL-DEMOCRATIC REVOLUTION OF 1917-1921: EXPERIENCE FOR CONTEMPORARY AGRARIAN TRANSFORMATIONS*
}

\author{
Serhii Kornovenko \\ Bohdan Khmelnytsky National University of Cherkasy (Cherkasy, Ukraine) \\ e-mail: s-kornovenko@ukr.net \\ ORCID: https://orcid.org/0000-0002-6268-2321
}

The experience of the events of the Ukrainian Revolution of 1917-1921 is especially relevant for modern Ukraine. Modern geopolitical transformations, radical changes in the domestic political life of Ukraine, ambitious plans of the government are a chance for our state to restore its full-fledged subjectivity in the international arena, in the domestic life of the country. An effective mechanism of external and internal subjectivization of Ukraine, given the longevity of agricultural culture (in a broad sense), can be agrarian policy, its effective implementation. This implies not only a clear understanding on the part of the state of the essence of agrarian policy, its purpose, stages and mechanisms of implementation.

The author of the article aims to propose, taking into account the agrarian transformations of the Ukrainian revolution, a possible model of the latest agrarian transformations.

Under modern conditions, the most discussed issue is the feasibility/inexpediency of opening a land market in Ukraine. The heated debate on this is primarily about the socio-economic and socio-political consequences. Last but not least, the debaters in the discussions focus on only one segment of this multifaceted phenomenon - foreign land tenure/land use/land management. That is, they are only interested in the institution of private land ownership for foreigners on the whole set of issues.

The main risks of opening the land market: external and internal. External: desubjectification of Ukraine, increasing dependence on foreign capital, especially credit one, loss of status of the granary of Europe, reduction of foreign exchange earnings to the budget, desoilization (dechernozemization). Internal: legalization of the agrarian oligarchy, desubjectification of power, degradation of civil society, increasing shadowing of the economy in general, agro-industrial complex in particular, the absence of the middle class - the social basis of the state, the extinction of the countryside, its disappearance as a socio-economic, socio-political, spiritual-cultural component of the Ukrainian political nation, strengthening the demographic challenges, etc.

Keywords: agrarianism, Ukrainian agrarianism, peasant revolution, Ukrainian revolution, peasantry

The peasant factor became decisive in the history of Ukraine in the early twentieth century. It showed itself especially clearly during the Ukrainian Revolution of 1917-1921. All participants in the revolutionary events in Ukraine, without exception, considered the solution of the agrarian issue to be the cornerstone of their domestic policy. The political destiny of one or another political regime - a participant in the revolutionary struggle in Ukraine, largely depended on the content, nature, and effectiveness of agrarian reforms. The peasantry became a powerful factor determining the future of one or another form of statehood.

\footnotetext{
${ }^{*}$ The article is written in accordance with the state budget theme «Ukrainian Revolution (1917-1921): The peasant factor» (state registration number 0118U003864).
} 
The peasantry of that time declared itself as an active subject of history, the social basis of one or another form of statehood. Revolutionary experience is more relevant than ever in modern Ukraine. As a hundred years ago, so now, an important factor in the subjectivity of Ukrainian statehood is the peasantry. The present and future of Ukraine's socio-economic development, the material well-being of its citizens depend on the solution of the agrarian issue in modern Ukraine. In view of this, the experience of agrarian transformations of the period of the Ukrainian revolution is a guarantee, if not the avoidance of mistakes, then at least the mitigation of possible negative consequences of the latest transformations in the field of land use / land tenure.

The author of the article aims to propose, taking into account the agrarian transformations of the Ukrainian revolution, a possible model of the latest agrarian transformations. Its content should relate to the peasant-owner with the optimal amount of land tenure / land use for cost-effective high-tech use.

Modern geopolitical transformations, radical changes in the domestic political life of Ukraine, ambitious plans of the government are a chance for our state to restore its fullfledged subjectivity in the international arena, in the domestic life of the country. An effective mechanism of external and internal subjectivization of Ukraine, given the longevity of agricultural culture (in a broad sense), can be agrarian policy, its effective implementation. This implies not only a clear understanding on the part of the state of the essence of agricultural policy, its purpose, stages and mechanisms of implementation. First of all, a comprehensive understanding and awareness of such a phenomenon as agrarian policy is actualized, not only such its structural components as socio-economic and socio-political, but also close ties with the land of the Ukrainian people throughout its history (agrarian archetype of the Ukrainian political nation), identification in the ideology of the Ukrainian (citizen) of such concepts as land = homeland = Ukraine, the task of the modern political vector on deoligarchization and the construction of not declared but real civil society and so on. That is, the idea of land is pervasive for the ideology of the Ukrainian political nation. It is a pervasive ideological unifying component for the Ukrainian political nation, a determining factor for the future. Taking into account the above, we believe that understanding the ideology of modern agricultural policy in Ukraine, the development of its principles is relevant.

In the modern historical and scientific literature there is a well-established opinion that agrarianism originated in Germany in the works of G. Ruland and A.Scheffle. Subsequently, he penetrates the territory of France, represented by the concept of J. Melin. In the late nineteenth - early twentieth century agrarianism penetrates into Eastern Europe - Poland, Bulgaria, Romania, the Czech Republic and Slovakia (later Czechoslovakia) ${ }^{1}$.

The land market in Ukraine has its own history and traditions. It is not an innovation that is so emotionally talked about in the media, social networks, etc ${ }^{2}$. It took place, given the moment of historicism, and in princely times, and in the Cossack era, and in the imperial period of history, and during the Ukrainian Revolution of 1917-192133, as well as

\footnotetext{
1 Галушко К. «Хліборобська ідеологія» В. Липинського у системі східноєвропейського аграризму // Український історичний збірник. 2000. № 2. С. 164-166.

2 Зось-Кіор М., Кирилюк Є., Корновенко С., Шарий Г. Гарантування продовольчої безпеки в контексті розвитку земельних відносин. Черкаси: ФОП Чабаненко, 2017.

3 Корновенко С., Земзюліна Н. Революційні потрясіння початку XX ст.: аграрне законодавство країн Центральної та Південно-східної Європи // Український селянин. 2018. Вип. 19. С. 45-49.
} 
under Soviet rule during the new economic policy (1921-1928). The Bolsheviks put an end to it in the Union of Soviet Socialist Republics / Ukrainian Socialist Soviet Republic / Ukrainian Soviet Socialist Republic, de facto destroying first large and then peasant land tenure/land use, introducing a state-farm-collective farm system of land management. This was due to the fact that the socialist model a priori did not recognize the institution of private property law, derived from which is the land market. With the proclamation of Ukraine's independence, with changes in the socio-economic and socio-political model of the state, with the restoration of the institution of private property, the land market gained further development. From 1991 until now, it has had features of evolution.

Under modern conditions, the most discussed issue is the feasibility/inexpediency of opening a land market in Ukraine. The heated debate on this is primarily about the socioeconomic and socio-political consequences. Not the least, the debaters in the discussions focus on only one segment of this multifaceted phenomenon - foreign land tenure/land use/land management. That is, on the whole set of issues they are only interested in the institution of private land ownership for foreigners. Undoubtedly, this issue is important, but not so much that missing the wood for the trees. In addition, it does not apply to the entire agricultural policy, but only one of its components, the land market cannot be the ultimate goal of agricultural policy, and therefore such an approach distorts the comprehensive understanding and understanding of agricultural policy. In our opinion, «land market» and «agricultural policy» are not identical concepts.

According to the draft law «On Land Market» 4 , considered by the Verkhovna Rada of Ukraine in the first reading on November 13, 2019, «land market - a system of legal, organizational and economic relations established in the process of trade in land based on determining the market value of these plots».

Agrarian policy is a component of domestic economic policy that contains socioeconomic and socio-political components. The socio-economic part deals with such key issues in the life of the peasantry as land reform and settlement of current agricultural affairs: improving land management, improving agro-technical tillage, providing agricultural machinery with machinery and technology, seed stock, fertilizers and more ${ }^{5}$. The socio-political aspect concerns the forms and methods of cooperation between the authorities and the peasantry.

Agrarian policy is sometimes equated with land policy. In our opinion, land policy is an important component of agrarian one, but it is more about the conditions of agricultural production than the production itself. The agrarian and land issues are also considered to be identical. In our opinion, they relate to each other as agrarian and land policy, i.e., the land issue - a component of agrarian, more about the forms of land ownership than production relations. The agrarian issue is the question of forms of land ownership, types of agricultural enterprises, laws of agricultural development, etc.

The main risks from the opening of the land market: external and domestic.

External:

1) desubjectification of Ukraine;

2) increasing dependence on foreign capital, especially credit one;

3) loss of the status of the granary of Europe;

\footnotetext{
4 Проект Закону про внесення змін до деяких законодавчих актів України щодо обігу земель сільськогосподарського призначення.

URL:

http://w1.c1.rada.gov.ua/pls/zweb2/webproc4_2?id=\&pf3516=2178-10\&skl=10

5 Коріненко П. Історія українського селянства. Тернопіль, 2014. 296 с.
} 
4) reduction of foreign exchange revenues to the budget;

5) desoilization (dechernozemization), etc.

Internal:

1) legalization of the agar oligarchy;

2) desubjectification of power;

3) degradation of civil society;

4) strengthening the shadowing of the economy in general, the agro-industrial complex in particular;

5) the absence of the middle class - the social basis of the state;

6) the extinction of the village, its disappearance as a socio-economic, socio-political, spiritual and cultural component of the Ukrainian political nation;

7) aggravation of the demographic challenges, etc.

Prospects (positive) of Ukraine from the opening of the land market. Depend on the opening mechanisms and rules of the land market. In the case of the implementation of agrarian (peasant / pro-Ukrainian) ideology: external, internal.

External:

1) subjectivization of Ukraine;

2) reduction of dependence on foreign capital, primarily credit one;

3) improving the investment attractiveness of Ukraine for foreign investors;

4) strengthening Ukraine's position in the European market of agricultural products, etc.

Internal:

1) de-oligarchization of Ukraine;

2) the subjectivization of power, the growth of its not a rating, but a real authority in society;

3) citizenization of Ukraine, creation of a large middle class of landowners, preservation of Ukrainian culture and spirituality;

4) de-shadowing of the economy in general, the agro-industrial complex in particular;

5) solving the demographic challenges in Ukraine in general, in the agro-industrial complex in particular;

6) solving the challenge of rural depression, intensification of the agro-industrial complex, its productization;

7) formation of modern infrastructure in the countryside;

8) saturation of the domestic market with quality domestic agricultural products;

9) accumulation of internal financial reserves, etc.

Tools for achieving positive from the opening of the land market (possible):

1. creation of a comprehensive land cadastre with online access. Until the opening of the land market to conduct a full audit of land. Create an online resource (map) with clear coordinates of land plots, forms of ownership and data on tenants. Data on the owner is entered by the owner himself (authorized person, state body), he also puts a special mark on the desire to sell the land. With the opening of the land market, first of all, allow the sale of private land holdings (shares). Preference for the sale is given to the existing tenant, who processes it for at least 3 years. To lease state lands through the Prozorro system;

2. to open state lands gradually (at the first stage to be limited to rent), after exhaustion of the already existing land market, first of all for land supply of Ukrainian citizens. The controlling stake is state-owned. As a possible option. Sale of land to new farmers, regardless of organizational form (LLC, PLLC, PFE), should be carried out as 
follows: first lease for 5 years, after checking the quality of land use (profitability of the farm, soil quality is not lower than at the time of lease)) the decision to sell it is made. Also pay attention to compliance with the conditions when concluding land lease agreements. Limit them to 10 years and terminate them only for gross breaches of the contract (non-payment of funds, non-fulfilment of obligations to cultivate homesteads, etc.) to reduce the incidence of dragging shares before the expiration of the lease. If the land is leased and not cultivated for two years, the tenant is deprived of the right to lease;

3. Amalgamated territorial community (ATC) is the regulator of the local land market;

4. the size of individual land ownership - 300-500 hectares. For example, in Hungary no more than 300 hectares for legal entities and individuals, Romania - no more than 200 hectares, Denmark - no more than 30 hectares. It all depends on the size of the reserves of agricultural land in a country;

5. the size of collective, cooperative, etc. land ownership from 500 to 10,000 hectares;

6. the size of the combined (public-private, agricultural holding, etc.) land tenure from 10,000 to 50,000 hectares. With a gradual, over 5-10 years, increase in size. Increase step - 10000 hectares;

7. the share of the state in combined land ownership (public-private, agricultural holding, etc.) should not be less than $51 \%$.

8. for Ukrainian citizens - a triad of property rights to land, for foreigners - a truncated triad: use and disposal without possession (as a possible option + any other). Similar truncation of property rights to foreigners was used in the Czech Republic, Slovakia, Lithuania, Bulgaria, and Hungary. In the US, only US citizens can buy land. Most American farmers are not landowners but tenants. That is, it is a pan-European and world practice both in general and at the initial stage of reform;

9. Application of the rules of pre-emptive law for Ukrainian individuals or legal entities in the acquisition of land rights, land tenure/land use. In science (for example, V. Makarova) there are three main types of pre-emptive rights: 1) the right of precedence in inheritance processes, which can be given to the heir (heirs) who wants (who want) to continue to manage the land; 2 ) the right of preference may be granted to one buyer over others because he is a tenant of the land being sold, or because he is a farmer whose farm borders the land being sold, or if the land being sold is in a common property because he is a co-owner; 3 ) the right of priority belonging to the state and (or) municipalities ${ }^{6}$;

10. Foreign persons may join the Ukrainian land market indirectly - by investing in agro-industrial business or using land that is pledged, without the right of ownership;

11. land is the object of banking and financial, etc. operations. However, a Ukrainian landowner is not deprived of his rights in case of land pledge. The land is pledged until the landowner's debt, credit, etc. is reimbursed as a result of its sublease. State institutions - their regulators;

12. development of lease relations in the countryside. They can be attended by both domestic and foreign business entities. The advantage of medium-term lease - not less than 5 and not more than 25 years. Under conditions of proper management of the leased land, further prolongation. Prolongation step - 5-10 years. Compliance with state standards in the management of leased land for 40 years is one of the criteria for the legal transfer of land to private ownership of domestic agricultural producers.

\footnotetext{
6 Макарова В. Зарубіжний досвід функціонування ринку земель сільськогосподарського призначення. URL: http://www.rusnauka.com/21_DNIS_2009/Economics/49110.doc.htm
} 
Thus, the land market is a structural component of agricultural policy. Accordingly, the concept of agricultural policy is broader, absorbing the concept of land market. Therefore, the identification of the land market with agricultural policy is insignificant. At the same time, it is insignificant to consider these concepts without the unity of their relationship. The discussion should concern a much broader category - the ideology of agrarian policy. The development of the latter involves recourse to European and national experience in this area.

The agrarian issue on the European continent has always been relevant. This applies to both the past and the present. Different countries of Europe at different stages of historical development have chosen different ideologies of agricultural policy. One of them during the XIX - first third of the XX century in Europe there was agrarianism.

In the late nineteenth - early twentieth century agrarianism, which originated in Germany in the works of G. Ruland and A. Scheffle 7 , represented in France by the concept of J. Melin, penetrated into Eastern Europe - Poland, Bulgaria, Romania, the Czech Republic and Slovakia (later - Czechoslovakia). Among the reasons for the emergence of agrarianism, researchers agree that it was due to the following factors: first, the agrarian nature of the economies of Eastern European countries; secondly, the severity of the agrarian issue in these countries; third, the numerical dominance of the peasantry over other segments of the population of Eastern European countries; fourth, the increased interest of society in agricultural issues in general and the peasantry in particular8.

In our opinion, in addition to the above, the reasons for the emergence of agrarianism were as follows. First, the conflict between industrial and agrarian civilizations under modernism.

Secondly, the development of the political culture of agrarian nations. The political cultures of Polish, Bulgarian, Czechoslovak, Romanian, Ukrainian, and other peasants underwent value modernization. There was a significant socio-cultural shift in the collective and individual political culture and consciousness of the peasants - the transition from indifferent political culture and consciousness to activist.

Third, the objective laws of the development of the actual agrarian civilization, the formation in its bowels of a qualitatively different peasantry. In the case of Ukraine, the peasant-ideoman - the active subject of history. The unifying value was the «Idea of the Land», its distribution on fair, in their understanding, principles.

In our opinion, in a broad sense, Eastern European agrarianism of the first third of the twentieth century - a holistic socio-cultural phenomenon, a phenomenon of Eastern European history of the first third of the twentieth century, due to objective-subjectivesubjective factors that are the object of knowledge. In a narrower sense, Eastern European agrarianism is a system of peasant-centric ideas of various subjects of the socio-cultural space of Eastern Europe in the first third of the twentieth century and their practical implementation. Concretizing a narrower understanding of Eastern European agrarianism of the first third of the twentieth century, we state that it is a system of ideas about peasants, peasants about themselves, about the peasantry as an active subject of history, capable of independent state-building; component of domestic economic policy

\footnotetext{
7 Josef Harna. Materiály k politickým, hospodářským a sociálním dějinám Československa v letech 19181929. / Spoluautoři: Zdeněk Deyl, Vlastislav Lacina. Praha: Ústav československých a světových dějin CSAV, 1981. S. 101-108.

8 Корновенко С., Земзюліна Н. Революційні потрясіння початку XX ст.: аграрне законодавство країн Центральної та Південно-східної Європи // Український селянин. 2018. Вип. 19. С. 45-49.
} 
aimed at solving the agrarian/peasant issue; as the peasants' self-awareness of themselves, as the peasants' political culture and political consciousness, as the realization in practice of the peasants' hopes and ideas about their just future; component of socio- and party-political thought 9 .

Ukrainian agrarianism reflected the agrarian character of Ukrainian society. Ukrainian agrarianism witnessed the transition from the indifferent political culture and consciousness of the Ukrainian peasantry to the activist, agrarian character of the emerging Ukrainian nation ${ }^{10}$.

Ukrainian agrarianism was represented, first, by the peasant-centric opinion of public figures; secondly, peasant-centric party-political thought; third, domestic economic policy aimed at resolving the agrarian/peasant issue; fourth, the peasants' self-awareness of themselves as a peasant's political culture and political consciousness, as the realization in practice of the peasants' own hopes and ideas about their just future.

Regarding the first. In the Ukrainian public and journalistic discourse in the early twentieth century. the peasant-centric view of Ukrainianness, the peasant character of the Ukrainian nation, the separateness of the city and the village, the urban and rural worldview and way of life was finally established. In the ideas of public and cultural figures (M. Drahomanov, S. Podolynsky, B. Hrinchenko, I. Franko, O. Rusov, S. Yefremov and others) it was considered axiomatic to identify such concepts as «Ukrainian peasantry», «Ukrainian nation», «Ukrainian people». Thus, there are enough reasons to talk about formed during the second half of the nineteenth - early twentieth century Ukrainian peasant-centric public-publicist discourse as one of the manifestations of Ukrainian agrarianism.

Regarding the other. The ideology of Ukrainian agrarianism is presented in the program provisions of the Ukrainian Democratic Agrarian Party, the Ukrainian People's Community, the All-Ukrainian Union of Agrarians-Owners (Peasants), and the Ukrainian People's Party. At the heart of their state ideology was peasant-centrism. They connected the socio-political and socio-economic future of Ukraine with the peasantry. They understood it as an active subject of history, a source of nation-building.

Regarding the third. Ukrainian agrarianism was represented by the agrarian policy of P. Skoropadsky and P.Wrangel. Their agrarian reforms were aimed at satisfying the socio-economic interests of the peasantry, strengthening its legal status. In both cases, the peasantry was considered the social basis of statehood, its interests were understood as state interests ${ }^{11}$.

Regarding the fourth. A characteristic feature of Ukrainian agrarianism was that it became the political culture of the peasantry, a reflection of their socio-economic and socio-political ideas. The embodiment of Ukrainian agrarianism as a system of peasant ideas about themselves were the peasant republics of the period of the Ukrainian Revolution of 1917-1921, some of which lasted until the second half of the 1920s.

Agrarian reforms in Poland, Bulgaria, Romania, and Czechoslovakia were implemented on the basis of agrarianism in the 1920's. They were effective and ensured the sustainable development of these countries in the interwar period. Leaders of Bulgarian agrarianists

\footnotetext{
9 Корновенко С. Суб'єктний складник аграрного питання як одна з передумов Української революції 1917-1921 рр. // Український історичний журнал. 2017. № 4. С. 83-94.

10 Галушко К. «Хліборобська ідеологія» В. Липинського у системі східноєвропейського аграризму // Український історичний збірник. 2000. № 2. С. 164-200.

11 Скоропадський П. Спогади. Київ: Філадельфія, 1995. 493 с.
} 
O. Stamboliyski and Czechoslovak M. Hodza headed the governments of their countries.

In the latest Ukrainian realities, agrarianism is a peasant-centric ideology of agrarian policy (as one of the aspects of this phenomenon) ${ }^{12}$. Accordingly, the peasant-owner is an active subject of nation-building, the basis of the Ukrainian political nation as a sociocultural phenomenon, the bearer of Ukrainian culture and spirituality.

The basic ideologeme of the agrarianist by its content agrarian policy in the socioeconomic sphere is the formation and development of high-commodity/high-tech agriculture, the numerically dominant stratum of the middle-class peasant-owner (middle class of Ukraine), modern rural infrastructure.

The basic ideologeme of the agrarianist by its content agrarian policy in the sociopolitical sphere is the formation and development of an active subject of Ukrainian statebuilding, a subject of the Ukrainian political nation - the peasant-owner (citizen). In this way, instead of decentralization (a destructive phenomenon for the state that denies its subjectivization), a model of citizenization/subjectivization of Ukraine is built: peasantcitizen - rural community - civil society - Ukraine. The existence of an agrarian oligarchy will be impossible.

The basic ideologeme of the agrarianist by its content agrarian policy is the idea that latifundism, large landholdings - a dead end branch of development of the agro-industrial complex of Ukraine, as it determines the agrarian oligarchy. High-commodity/high-tech medium-sized land tenure (300-500 ha) is a prospect for the development of modern agro-industrial complex of Ukraine, as it creates competition in the industry, makes it impossible to oligarchize agro-industrial complex. At the same time, a reasonable balance between the number of small/medium and large landowners, their agricultural production is optimal;

The basic ideologeme of agrarianist by its content agrarian policy is the creation and effective functioning of the State Land Bank. At one time such an institution was the bank «Ukraine». Its main functions:

1) valuation of land to be sold;

2) distribution of lands that will be transferred to the bank's land fund;

3) determination of the maximum and minimum sizes of plots that peasants can buy from a bank, etc.

The basic ideologeme of the agrarianist by its content agrarian policy is the creation and effective functioning of the exchange of agricultural products. In this way the risks of shadowing of the agro-industrial complex are minimized. The producer of agricultural products will have a personal opportunity to sell agricultural products without unnecessary intermediaries.

The basic ideologeme of the agrarianist by its content agrarian policy is the development of a methodology for land value. As an option. The basis can be taken to determine the net yield of a hectare of agricultural land for 3-5 years, which is capitalized in a certain percentage. The calculations made in this way can correlate regional market land prices. At the same time take into account soil fertility. On the basis of statistics on yields for the last 3-5 years to deduce averages. Then multiply the average firm food prices by the average yield, this will be the average gross profitability per hectare. Subtracting from this indicator the costs associated with tillage, purchase of seed funds,

\footnotetext{
12 Kornovenko S., Pasichna Y. Eastern European agrarianism. Ukrainian intellectual space in the late 19th and early 20th centuries // Український селянин. 2019. Вип. 22. С. 24-29.
} 
etc., we obtain a net return on land, and by capitalization - its value.

Another option. The value of the land is calculated as follows: the owner must receive for the land such an amount of money that is not less than the rent that he would have received for 5 years for renting it.

Such approaches will reduce the risk of abuse in price formation practices.

The basic ideologeme of the agrarianist by its content agrarian policy is socially responsible agro-industrial business. The tool is to amend the Tax Code. In particular, the agricultural entity pays taxes at the place of business, not the registration of an individual/legal entity. In practice, the farmer has to pay taxes to the ATC in which he rents, regardless of the place of registration. 50\% VAT after payment must be returned to the special account of the agricultural manufacturer. For this amount he buys fuels and lubricants, plant protection products, basic mineral fertilizers. The other $50 \%$ should be transferred to the special account of the ATC and spent on the maintenance of educational institutions and socio-cultural sphere of the village in the territory where the agricultural manufacturer cultivates the land. For livestock, the ratio should be $75 \%$ to the farm and $25 \%$ to the village.

The basic ideologeme of the agrarianist by its content agrarian policy is ecologically and technologically responsible agro-industrial business, not consumer-predatory. The subject of agricultural activity, regardless of the forms of land tenure / land use, is obliged to comply with state standards of agriculture, crop rotation, etc. Fertility and soil quality should be checked by authorized state authorities, experts at least once every three years. For reduction of quality indicators to apply penalties up to deprivation of the right of rent. Pesticides used by an agricultural manufacturer must be registered in Ukraine, and the owner or tenant must report annually on the application of pesticides and agrochemicals with the obligation to provide supporting documents for their purchase. Sales should only be made by sellers who have a state license to sell and the appropriate infrastructure for their storage.

The basic ideologeme of the agrarianist by its content agrarian policy is interest-free loans, and in some cases - non-repayable loans: for the purchase of land on the secondary land market, land reclamation, the use of advanced agricultural technologies, rural business development, construction, education, health care and more. Provision of state and commercial loans to peasants, primarily mortgage lending. Such measures, first, will expand the range of potential domestic buyers of land; secondly, to some extent contribute to the recovery of the credit and financial system; thirdly, they will promote the commodification of agricultural production on the basis of the latest technologies. At the same time, lending should be smart, one that encourages development, not corrupts the agricultural manufacturer.

The basic ideologeme the agrarianist by its content agrarian policy is the development of agricultural cooperation: consumer, credit, processing, and so on. Agricultural cooperation is an effective and priority form of economic activity in agriculture. One of the forms is MTS, service of agricultural machinery, etc.

The basic ideologeme of the agrarianist by its content agrarian policy is to stimulate the development of individual, cooperative, collective farms by attracting domestic and foreign investment, tax benefits, legal protection of agrarian business and land tenure/land use by the state, etc. First of all, the creation of a legal framework that would prevent raiding, unfair leases, and so on.

The basic ideologeme of the agrarianist by its content agrarian policy is to create 
favourable conditions for the development of small and medium-sized agricultural industries. Transition from the raw material model of agro-industrial complex to commodity with a full cycle. Development of transport infrastructure: tracks, water transport, road transport. Development of a network of storage and processing enterprises: elevators, mills, canning meat and dairy, etc. medium-power complexes.

The basic ideologeme of the agrarianist by its content agrarian policy is the development of the socio-cultural sphere: educational and cultural institutions in the countryside, modern medical institutions, the provision of the full range of modern medical services and more.

The basic ideologeme of the agrarianist by its content agrarian policy is measures to rejuvenate the countryside, stabilize the demographic situation in the countryside, the beginning of its positive dynamics. Training for agro-industrial complex, socio-economic incentives for employment in agro-industrial complex. Measures to implement the program «Return of workers to Ukraine». They leave on the best terms of payment, social and living conditions, prospects, etc. Their presence in the Ukrainian agro-industrial complex will stop the outflow of youth, stop the demographic decline, contribute to the rejuvenation of the countryside.

Thus, the land market is a structural component of agricultural policy. Accordingly, the concept of agricultural policy is broader, absorbing the concept of land market. Therefore, the identification of the land market with agricultural policy is insignificant. At the same time, it is insignificant to consider these concepts without the unity of their relationship. The discussion should concern a much broader category - the ideology of agrarian policy. The development of the latter involves recourse to European and national experience in this area.

\section{REFERENCES}

Halushko, K. (2000). «Khliborobska ideolohiia» V. Lypynskoho u systemi skhidnoievropeiskoho ahraryzmu [«Agricultural ideology» by V. Lypynsky in the system of Eastern European agrarianism]. Ukrainskyi istorychnyi zbirnyk, 2, 164-200 [in Ukrainian].

Josef, H. (1981). Materiály k politickým, hospodářským a sociálním dějinám Československa v letech 19181929. Praha: Ústav československých a světových dějin CSAV [in Czech].

Korinenko, P. (2014). Istoriia ukrainskoho selianstva [History of the Ukrainian peasantry]. Ternopil [in Ukrainian].

Kornovenko, S. \& Pasichna, Y. (2019). Eastern european agrarianism. Ukrainian intellectual space in the late $19^{\text {th }}$ and early $20^{\text {th }}$ centuries. Ukrayins'kyy selyanyn, 22, 24-29. DOI: $10.31651 / 2413-8142-$ 2020-23-28-30.

Kornovenko, S. \& Zemziulina, N. (2018). Revoliutsiini potriasinnia pochatku XX st.: ahrarne zakonodavstvo krain Tsentralnoi ta Pivdenno-skhidnoi Yevropy [Revolutionary Disturbances in the early XX century: Agrarian Law of Central and South Eastern Europe]. Ukrainskyi selianyn, 19, 45-49 [in Ukrainian].

Kornovenko, S. (2017). Subiektnyi skladnyk ahrarnoho pytannia yak odna z peredumov Ukrainskoi revoliutsii 1917-1921 rr. [Subjective component of the agrarian question as one of the preconditions of the Ukrainian revolution of 1917-1921]. Ukrainskyi istorychnyi zhurnal, 4, 83-94 [in Ukrainian].

Makarova, V. Zarubizhnyi dosvid funktsionuvannia rynku zemel silskohospodarskoho pryznachennia [Foreign experience in the functioning of the agricultural land market]. Retrieved from http://www.rusnauka.com/21_DNIS_2009/Economics/49110.doc.htm [in Ukrainian].

Skoropadskyi, P. (1995). Spohady [Memories]. Kyiv: Filadelfiia [in Ukrainian].

Zos-Kior, M., Kyryliuk, Ye., Kornovenko, S. \& Sharyi, H. (2017). Harantuvannia prodovolchoi bezpeky v konteksti rozvytku zemelnykh vidnosyn [Guaranteeing food security in the context of land relations development]. Cherkasy: FOP Chabanenko [in Ukrainian]. 


\section{Сергій Корновенко}

(Черкаський національний університет імені Богдана Хмельницького, м. Черкаси, Україна)

e-mail: s-kornovenko@ukr.net

ORCID: https://orcid.org/0000-0002-6268-2321

\section{Аграрна політика в Україні періоду Національно-демократичної революції 1917- 1921 рр.: досвід для сучасних аграрних перетворень}

Досвід подій Української революції 1917-1921 рр. є особливо актуальним для сучасної України. Сучасні геополітичні трансформації, докорінні зміни у внутрішньополітичному житті України, амбітні плани влади $є$ шансом для нашої держави відновити її повноцінну суб'єктність на міжнародній арені, у внутрішньому житті країни. Дієвим механізмом зовнішньої та внутрішньої суб'єктивізації України, зважаючи на тяглість землеробської культури (у широкому сенсі), може стати аграрна політика, іï ефективна реалізація. Це передбачає не лише чітке розуміння з боку держави сутності аграрної політики, її мети, етапів і механізмів запровадження.

Автор статті ставить за мету запропонувати, з урахуванням аграрних перетворень Української революції, можливу модель новітніх аграрних перетворень.

За сучасних умов найобговорюванішим $є$ питання доцільності/недоцільності відкриття в Україні ринку земель. Гострі дебати стосовно цього точаться насамперед навколо соціально-економічних і суспільно-політичних наслідків. Не в останню чергу диспутанти у дискусіях фокусуються лише на одному сегменті цього багатогранного явища - іноземне землеволодіння/землекористування/землерозпорядження. Тобто, їх із усього комплексу питань цікавить лише інститут приватної власності на землю для іноземних осіб.

Основні ризики від відкриття ринку земель: зовнішні та внутрішньополітичні. Зовнішні: десуб’єктивізація України, посилення залежності від іноземного капіталу, насамперед кредитного, втрата статусу житниці Європи, зменшення валютних надходжень до бюджету, дегрунтизація (дечорноземізація). Внутрішні: узаконення агарного олігархату, десуб'єктивізація влади, деградація громадянського суспільства, посилення тінізації економіки загалом, аграрно-промислового комплексу зокрема, відсутність середнього класу - соціальної основи держави, вимирання села, його зникнення як соціально-економічного, суспільно-політичного, духовно-культурного компоненту української політичної нації, посилення демографічної проблеми тощо.

Ключові слова: аграризм, український аграризм, селянська революція, Українська революція, селянство 